\title{
Statistical Analysis of Citizen's Personal Income Tax Compliance in Lagos State, Nigeria
}

\author{
Saidi O. Amusa Emmanuel M. Ikegwu* Gbenga I. Bamidele Esther A. Ojebiyi \\ Department of Statistics, Yaba College of Technology, Yaba Lagos
}

\begin{abstract}
This study focused on tax compliance in Lagos State, Nigeria among employees that are gainfully employed. A survey design was adopted for collecting data with a self - designed questionnaire administered among residents of Shomolu Local Government Area. The instrument was validated by experts and through a pilot study and the Cronbach's Alpha reliability coefficient was 0.834. A two - stage sampling technique was used to select 344 respondents of which 318 were completed, returned and used. The data thus collected were analysed using descriptive statistics, Spearman's correlation and Chi-square tests with the aid of Statistical Package for Social Sciences (SPSS). The result showed that tax compliance was $74.9 \%$ and there is significant positive relationship between taxpayers' tax compliance (TTC) and the revenue generation (RG) in Lagos ( $<0.05)$, tax morale (TM) $(\mathrm{p}<0.05)$ and taxpayer's confidence in legal system $(\mathrm{TCL})(\mathrm{p}<0.05)$. However, a significant negative relationship exists between taxpayers' tax compliance (TTC) and tax rate (TR) $(\mathrm{p}<0.05)$. It is therefore concluded that a high tax morale and high taxpayers' confidence in the legal systems will enhance their tax compliance which in turn will lead to higher revenue generation in Lagos. It was recommended that Government should boost the morale of tax payers through accountability and efficient utilisation of taxpayers' fund in providing qualitative education, free and affordable healthcare and good roads; implement the available laws to enhance taxpayers' confidence in the legal systems and reduce existing tax rates to enhance tax compliance among the citizenry.
\end{abstract}

Keywords: Tax Compliance, Tax Morale, Revenue, Taxpayers' Confidence, Spearman's correlation

DOI: $10.7176 / \mathrm{JESD} / 10-22-14$

Publication date: November $30^{\text {th }} 2019$

\section{Introduction}

It is widely acknowledged that people do not like paying taxes especially in developing countries (Alm \& Martinez-Vazquez, 2003) as a result of mismanagement of public fund by public administrators. Tax is a compulsory contribution to state revenue levied by the government on individual's income and business profits or value added to the cost of qualifying goods, services and transactions. Taxpayers in such regions fail to comply with their country's existing tax laws and administrators also do not enforce such laws because they are not accountable nor faithful in the handling of public trust. Tax non - compliance is the failure of taxpayer to meet tax obligations whether intentionally or unintentionally occurs through failure to file tax returns, misreporting taxable income, misreporting of allowable deductions from taxable income or tax due such as exemptions, deductions, tax credit, tax evasion, etc. (Kirchler, 2007; Roth, et al., 1996). The most obvious consequence of tax non - compliance is the loss of tax revenue to government and this limits funds for execution of projects. In addition, tax non compliance creates inequality among the people because both horizontal and vertical equity are affected (Alm \& Gomez, 2008). Tax non - compliance is a universal phenomenon hindering efficient tax revenue productivity in both developing and developed countries (Alabede, et al., 2011); Chau \& Leung, 2009). The growing responsibility of government coupled with its shrinking revenue made the issue of tax non - compliance, mostly, tax evasion and avoidance persist as the core focus of strategic decisions in most developed and developing countries. Hence, tax non - compliance have attracted research efforts in the recent past had produced a number of models which help understand tax compliance behaviour of taxpayers and led to conclude that economic, social, psychological and cultural factors are influencing tax compliance (Alabede, et al., 2011; Anyadiuba, et al., 2012)

Low tax compliance is serious problem in many developing countries because it restricts the capacity of government to raise revenue for developmental purposes (Braithwaite \& Braithwaite, 2000). Government is more likely to put in place developmental programmes for the enhancement of the living standard of the people the more revenue it receives. The problem addressed in this study is to determine the effect of taxpayers' tax morale on their compliance with tax policies of government as a useful avenue for revenue generation. The specific objectives include to determine the effect of tax compliance on the revenue generation in Lagos state, examine the relationship between tax rates and tax compliance, determine the effect of taxpayers' morale on their tax compliance and determine the effect of taxpayers' confidence in legal system on their tax compliance.

\section{Methodology}

This section explained the methods adopted in this study to determine the rate of tax compliance in Nigeria, using Lagos State. A cross-sectional survey design was adopted as data were collected from the target population through questionnaire. The data used were obtained from fully employed residents of Shomolu Local Government Area in 
Lagos State using a self- constructed questionnaire to obtain the required information. A two - stage sampling technique was used for the selection of the locality studied and actual respondents in the study. A sample size of 344 taxpayers from Shomolu Local Government Area of Lagos State were sampled purposively and supplied information needed in the questionnaire. The collected data was analysed descriptively using frequency distributions and Spearman's rank correlation coefficient and effects measured using chi - square analysis with the aid of Statistical Package for Social Sciences (SPSS 23). The Pearson Chi - Square Test $\left(\chi^{2}\right)$ is a statistical test applied to sets of categorical data to evaluate how likely it is that any observed difference between the sets arose by chance. It tests a null hypothesis stating that the frequency distribution of certain events observed in a sample is consistent with a particular theoretical distribution. The Chi - Square test statistic is given as:

$$
\chi^{2}=\sum \sum \frac{\left(O_{f}-E_{f}\right)^{2}}{E_{f}}
$$

Where: $O_{f}$ is the observed frequency and $E_{f}$ is the expected frequency

\section{Results}

The results were obtained from three hundred and eighteen (318) questionnaires fully completed and returned out of the three hundred and forty-four (344) administered resulting in $92.4 \%$ response rate.

Table 1: Distribution of respondents' demographic characteristics

\begin{tabular}{|c|c|c|c|}
\hline Variable & Category & Frequency & Percent \\
\hline \multirow[t]{3}{*}{ Gender } & Male & 140 & 44.0 \\
\hline & Female & 178 & 56.0 \\
\hline & Total & 318 & 100 \\
\hline \multirow[t]{6}{*}{ Age group } & $18-29$ & 109 & 34.2 \\
\hline & $30-39$ & 108 & 34.0 \\
\hline & $40-49$ & 67 & 21.1 \\
\hline & 50 and above & 32 & 10.1 \\
\hline & Non - response & 2 & 0.6 \\
\hline & Total & 318 & 100 \\
\hline \multirow[t]{9}{*}{ Highest educational level } & No formal education & 11 & 3.5 \\
\hline & O' level & 46 & 14.5 \\
\hline & ND/ NCE & 73 & 23.0 \\
\hline & $\mathrm{HND} / \mathrm{BSC}$ & 118 & 37.1 \\
\hline & $\mathrm{MBA} / \mathrm{MSc}$ & 25 & 7.9 \\
\hline & $\mathrm{PhD}$ & 34 & 10.7 \\
\hline & Professional certificate & 8 & 2.5 \\
\hline & Non - response & 3 & 0.9 \\
\hline & Total & 318 & 100 \\
\hline \multirow[t]{5}{*}{ Marital status } & Married & 148 & 46.5 \\
\hline & Single & 167 & 52.6 \\
\hline & Others & 2 & .6 \\
\hline & Non - response & 1 & .3 \\
\hline & Total & 318 & 100 \\
\hline \multirow[t]{4}{*}{ Religion } & Christian & 171 & 53.8 \\
\hline & Muslim & 135 & 42.5 \\
\hline & Traditional & 12 & 3.8 \\
\hline & Total & 318 & 100 \\
\hline \multirow[t]{5}{*}{ Working status } & Govt./public & 96 & 30.2 \\
\hline & Private/Industry & 83 & 26.1 \\
\hline & Self - employed & 137 & 43.1 \\
\hline & Non - response & 2 & 0.6 \\
\hline & Total & 318 & 100 \\
\hline \multirow[t]{6}{*}{ Income capacity } & Below 50,000 & 180 & 57.6 \\
\hline & $50,000-80,000$ & 72 & 22.6 \\
\hline & $80,000-110,000$ & 24 & 7.6 \\
\hline & Above 110,000 & 36 & 11.3 \\
\hline & Non - response & 6 & 1.9 \\
\hline & Total & 318 & 100 \\
\hline
\end{tabular}

The distributions of socio-demographic characteristics of respondents in table 1 shows that $44.0 \%$ of the 
taxpayers are male while $56.0 \%$ are female. Also, $34.2 \%$ of the taxpayers are below 30 years, $55.1 \%$ are between 30 and 50 years, $10.1 \%$ are above 50 years while $0.6 \%$ did not state their age. It shows that only $3.5 \%$ of the taxpayers have no formal education, $14.5 \%$ had O'level certificate, $60.1 \%$ attended tertiary education, $18.6 \%$ are holders of postgraduate certificate and only $2.5 \%$ have professional certification while $0.9 \%$ did not answer. In addition, $46.5 \%$ of them are married, $52.6 \%$ are single while $0.6 \%$ did not respond. It shows that $53.8 \%$ of taxpayers Christians, $42.5 \%$ are Moslems while only 3.8\% are traditionalist. Furthermore, $30.2 \%$ are government/ public organisation employees, $26.1 \%$ are employees in private organisation/ industry, $43.1 \%$ are self-employed while $0.6 \%$ did not state their work affiliation. Lastly, $57.6 \%$ of the respondents earn below \#50,000 monthly, $22.6 \%$ had an average monthly income between $\# 50,000$ and \#80,000, 7.6\% earned between \#80,000 - \#110,000 monthly and $11.3 \%$ earn above \#110,000 as average monthly income while $1.9 \%$ did not state their monthly income. Approximately, the average monthly income earned by the taxpayers is \#52,307.69 (sd = \#37,371.08).

Table 2: The factors that motivate taxpayers to pay tax in Nigeria.

\begin{tabular}{|c|c|c|c|c|c|}
\hline Issues & SD & D & $\mathbf{U}$ & A & SA \\
\hline I am satisfied with mode of tax collection adopted in my country & 17.0 & 11.3 & 10.4 & 39.0 & 22.3 \\
\hline Income generated from tax revenue has been impressive & 11.0 & 10.1 & 18.2 & 34.0 & 26.7 \\
\hline $\begin{array}{l}\text { Provision of social amenities such as education, health care centre, good } \\
\text { road etc. by government encourage me to pay tax }\end{array}$ & 11.0 & 11.3 & 7.5 & 39.6 & 30.5 \\
\hline $\begin{array}{l}\text { Subsidies on goods and services by government encourage my payment of } \\
\text { tax }\end{array}$ & 10.1 & 15.1 & 7.5 & 40.6 & 26.7 \\
\hline $\begin{array}{l}\text { I complied to pay tax because it serves as added internal revenue generated } \\
\text { for government }\end{array}$ & 6.9 & 9.7 & 8.5 & 43.1 & 31.8 \\
\hline The tax system practice in Nigeria is progressive in nature & 8.9 & 14.2 & 18.7 & 32.0 & 26.3 \\
\hline The tax system practice in Nigeria is regressive in nature & 21.5 & 28.7 & 25.9 & 17.0 & 6.9 \\
\hline Corporate profit tax rate in Nigeria is too high & 13.5 & 19.4 & 16.1 & 30.0 & 21.0 \\
\hline $\begin{array}{l}\text { Enlightenment and adequate utilisation of tax revenue on public goods } \\
\text { encourage tax payment }\end{array}$ & 9.5 & 7.0 & 8.3 & 38.1 & 37.1 \\
\hline The personal income tax rate in Nigeria is too high & 13.6 & 21.5 & 8.9 & 32.0 & 24.1 \\
\hline High level of corruption in the system discourage tax payer not to comply & 7.3 & 4.7 & 4.7 & 33.1 & 50.2 \\
\hline $\begin{array}{l}\text { The taxes collected in Nigeria have significant impact on agricultural } \\
\text { products }\end{array}$ & 13.3 & 9.8 & 48.9 & 17.5 & 10.5 \\
\hline I would neither pay tax nor encourage people to pay it if I had chance to & 33.5 & 25.6 & 14.6 & 16.1 & 10.1 \\
\hline High tax rate levy discourage investment & 18.7 & 17.5 & 9.2 & 28.9 & 25.7 \\
\hline I loss trust in the government and then decided not pay my tax & 38.3 & 22.5 & 11.1 & 15.5 & 12.7 \\
\hline I pay my tax regularly because of the legal system adopted in the country & 9.1 & 14.2 & 9.8 & 32.2 & 34.7 \\
\hline Weak enforcement discourages tax payer not to comply with payment of & 7.6 & 6.3 & 9.8 & 37.2 & 39.1 \\
\hline
\end{tabular}
their tax

Table 2 shows that $61.3 \%$ believed they are satisfied with mode of tax collection adopted in Nigeria, $60.7 \%$ agreed that income generated from tax revenue has been impressive, $70.1 \%$ agreed that provision of social amenities such as education, health care centre, good road etc. by government encourage taxpayers to pay tax and $67.3 \%$ agreed that subsidies on goods and services by government encourage payment of tax by the public. Also, $74.9 \%$ of the taxpayers complied to pay tax because it serves as added internal revenue generated for government, $58.3 \%$ confirmed that Nigeria practices progressive tax system and $23.9 \%$ agreed that Nigeria practices regressive tax system.

In addition, $51 \%$ of the taxpayers agreed that corporate profit tax rate in Nigeria were too high, $75.2 \%$ agreed that enlightenment and adequate utilisation of tax revenue on public goods will encourage tax payers to pay tax, $56.1 \%$ agreed that the personal income tax rate in Nigeria is too high and $83.3 \%$ agreed that high level of corruption in the country discourage payment of tax.

Lastly, only $28.0 \%$ of taxpayers agreed that taxes collected in Nigeria have significant impact on agricultural products system in the country, $26.2 \%$ agreed that they will neither pay nor encourage people to pay tax if they have the chance to, $54.6 \%$ agreed that investors are discouraged from investing in a particular country if the tax rate is too high, $28.2 \%$ of the taxpayers agreed they have lost trust in the present government and so decided not to pay tax, $66.9 \%$ agreed that the legal system adopted encourage them to pay tax and $76.3 \%$ agreed that weak enforcement discourages tax payer not to comply with the payment of tax. 
Table 3: Factors that serve to improve tax compliance in Nigeria.

\begin{tabular}{|c|c|c|c|c|c|}
\hline Factors & SD & D & $\mathbf{U}$ & A & SA \\
\hline Government needs to tackle corruption and make tax collector independent & & & & & \\
\hline & 1.9 & & & & \\
\hline Mod & 2.8 & & 3.2 & & \\
\hline ce of tax to our economy & 2.2 & 0.9 & 1.9 & 32.0 & \\
\hline $\begin{array}{l}\text { of job opportunities will encourage people to comply with duty } \\
\text { them }\end{array}$ & 1.3 & 0.9 & 2.2 & 31.1 & 64.2 \\
\hline social amenities encourage me to pay my tax & 2.5 & 3.2 & 1.6 & 5.2 & 57 \\
\hline f tax payment need be created by & 2.9 & 1.3 & 3.8 & 34.3 & 57.8 \\
\hline Government should introduce tax system that will favour the poor masses & 1.9 & 1.0 & 1.6 & 28.0 & 67.5 \\
\hline \multicolumn{6}{|c|}{$\begin{array}{l}\text { Table } 3 \text { above shows that } 92.1 \% \text { of the taxpayers concurred that government needs to tackle corruption an } \\
\text { nake tax collectors independent, } 95.2 \% \text { agreed that government needs to train tax collection officers, } 93.3 \% \text { agree } \\
\text { hat moderate tax should be levied on the low - income earners in order to encourage people to pay tax regularl } \\
\text { and } 95.0 \% \text { agreed that government should educate people/public on the importance of tax to economi } \\
\text { levelopment. Also, } 95.3 \% \text { agreed that provision of job opportunities will encourage people to comply with dut } \\
\text { evied on them, } 92.7 \% \text { believed that provision of social amenities will encourage the masses to pay their tax, } 92.1 \% \\
\text { greed that public enlightenment campaign of tax payment need be created by government to enhance tax paymen } \\
\text { ind } 95.5 \% \text { reinforced that government should introduce tax policy, such as progressive tax system, that will be } \\
\text { avour of the noor masses. }\end{array}$} \\
\hline
\end{tabular}

\subsection{Hypothesis testing}

$\mathrm{H}_{0}$ : There is no significant relationship between Tax Compliance and research variables

Table 4: Correlation coefficient between tax compliance and research variables

\begin{tabular}{|l|c|c|c|c|}
\hline Variables & r & Std. Error & t & Sig. \\
\hline Government Revenue Generation & 0.718 & 0.032 & 18.312 & $<0.001^{\mathrm{a}}$ \\
\hline High income tax rate & -0.134 & .057 & -2.395 & $0.017^{\mathrm{a}}$ \\
\hline Tax Morale & 0.589 & 0.042 & 12.945 & $<0.001^{\mathrm{a}}$ \\
\hline Confidence in Legal Systems & 0.427 & 0.051 & 8.377 & $<0.001^{\mathrm{a}}$ \\
\hline a. Based on normal approximation.
\end{tabular}

Table 3 revealed that the spearman's rank correlation coefficient between tax compliance and government revenue is $0.72(p<0.05)$. This implies that a high tax compliance will result in high government revenue. It is therefore concluded that there is a very strong, significant positive relationship between tax compliance and the government revenue generation in Nigeria. This signified that the regular payment of tax significantly and positively impacts on the growth of government's internally generated income. It also shows that the spearman's rank correlation coefficient between tax rate and tax compliance is -0.134 . We therefore conclude that there is a weak significant negative relationship between tax rate and tax compliance $(\mathrm{p}<0.05)$. This implies that high tax rate levied on individual's results. In addition, it revealed that the spearman's rank correlation coefficient between tax morale and tax compliance is 0.589 . It is therefore concluded that there is a strong, significant positive relationship between tax morale and tax compliance $(\mathrm{p}<0.05)$. This implies that the provision of social amenities such as health care centre, good road, education etc. which are means to raise taxpayers' morale encourage them to comply with payment of tax. Lastly, it also revealed the spearman's rank correlation coefficient between taxpayer's confidence in legal system and tax compliance is 0.427 . It is concluded therefore that there is weak, significant positive relationship between taxpayer's confidence in legal system and tax compliance $(p<0.05)$. This implied that confidence in the legal systems put in place by government encourage taxpayers to pay tax.

Table 5: Tax compliance across demographic characteristics

\begin{tabular}{|l|c|c|c|}
\hline Characteristics & Chi square value & df & p-value \\
\hline Gender & 0.003 & 1 & 1.000 \\
\hline Age group & 12.400 & 3 & 0.006 \\
\hline Marital Status & 0.053 & 1 & 0.897 \\
\hline Religion & 0.893 & 2 & 0.640 \\
\hline Highest educational qualification & 17.799 & 4 & 0.001 \\
\hline Work Sector & 15.670 & 2 & $<0.001$ \\
\hline Employee's Income category & 4.989 & 3 & 0.173 \\
\hline
\end{tabular}

Table 4 shows that proportion of compliance was significantly different only among the age categories, highest educational qualification and employees' work sector $(\mathrm{p}<0.05)$. It shows that higher proportion of government/ public employees $(89.6 \%)$ pay tax followed by self - employed $(70.8 \%)$ while least compliant are 
private/ industry employees $(66.3 \%)$. Among the age categories, employees 50 years and above are more compliant $(90.6 \%)$, followed by age $30-39$ years $(79.6 \%), 40-49$ years $(77.6 \%)$ while the least compliant are employees below 30 years $(64.2 \%)$. Lastly, Postgraduate holders are more compliant $(89.8 \%)$, followed by graduates $(75.9 \%)$, professionals $(75.0 \%)$, and the least compliant were those with no formal education $(54.5 \%)$ and O'level holders $(56.5 \%)$.

\section{Discussion}

The findings suggest that there are various reasons and facilitating factors for tax compliance in the Lagos State. In order to develop methods and instruments for fighting tax non-compliance among the taxpayers, it is important to foremost establish a broad understanding of the different reasons underlying these problems.

Firstly, it was found that there is significant positive relationship between tax compliance and the revenue generation of government in Nigeria. This implied that the where citizens regularly pay their tax, there will significant growth in the internally generated income of the government, i.e., increase in tax compliance tends to increase government revenue. This agreed with the findings of Ocheni (2015) and Okoye, et al. (2012) that revenue generation and tax compliance are positively correlated. Secondly, a significant negative relationship between tax rate and tax compliance $(\mathrm{p}<0.05)$ was established from the study. This implies that the higher the tax rate levied on taxpayers, the lower the level of tax compliance among the taxpayer. This finding was in line with observations in literature that high tax rate discourages taxpayers from paying tax or is disincentive to tax compliance (Ojo \& Oladipo, 2017; Okoye, et al., 2012; Ocheni, 2015). This is pertinent because tax payment reduces the available fund that could be channeled into other area sof demand in life and business. Furthermore, therefore, one can conclude that there is significant positive relationship between tax morale and tax compliance. Where there is high tax morale, taxpayers will be more tax compliant and vice versa. This finding was agreeable with the positions of (Okoye, et al., 2012; Anichebe, 2010; Nzotta, 2007). The accountability of government, and effective utilisation of taxpayers' contribution in provision of social amenities such as health care centre, good road, education etc. will encourage taxpayer to comply with prompt and full payment of tax. Lastly, conclude that there is significant positive relationship between taxpayer's confidence in legal system and tax compliance. Taxpayers' confidence in the operating legal systems put in place by government to prosecute evaders, deter corruption among tax officials, up - to - date tax laws and proper reporting systems encourage tax compliance agreeing with (Okoye, Akenbor, \& Obara, 2012; Anyadiuba, Eragbhe, \& Kennedy, 2012).

\section{Conclusion}

Reforming tax policies and strengthening tax administrations in developing countries like Nigeria is crucial to establish a 'level playing field' in tax matters between developing countries' administrations and well-informed taxpayers. Based on the analysis result and the findings the following conclusions were made: It is therefore concluded that tax policy like progressive tax should be adopted in the country in order to encourage compliance of tax payment. This system tends to apportion tax charges according to the weight of individual earning. It is concluded that government should put solid enforcement in place in order to encourage taxpayer to comply with tax payment. Appropriate law enforcement will deter tax defaulters and enhance internally income generated by government from local level to federal level because tax compliance has significant effect on tax revenue generated. Finally, it is concluded that the decreasing current tax rate will significantly encourage taxpayers' responses to pay tax.

\section{Recommendation}

Based on the analysis and findings the following recommendations were suggested: For a better tax administration, adequate machinery should be put in place and strengthened. The corrupt tax official should be discipline and remove, the tax collection mechanism used by tax officials must be free from corruption and embezzlement. The Federal Government, state governments and local governments should urgently fully modernise and automate all its tax system, improve tax payer convenience in the assessment and payment process whilst at the same time entrenching effective and modern human resource management practices in the tax authorities.

\section{References}

Alabede, J. O., Ariffin, Z. Z. \& Idris, K. M., 2011. Individual taxpayers' attitude and compliance behaviour in Nigeria: The moderating role of financial condition and risk preference. Journal of Accounting and Taxation, 3(5), pp. $91-104$.

Alm, J. \& Gomez, J. L., 2008. Social capital and tax morale in Spain. Economic Analysis and Policy, 38(1), pp. $34-47$.

Alm, J. \& Martinez-Vazquez, J., 2003. Institutions, Paradigms, and Tax Evasion in Developing and Transition Countries. Public Finance in Developing and Transitional Countries. Essays in Honor of Richard Bird. Cheltenham,. UK: Edward Elgar. 
Anichebe, A. S., 2010. Tax Evasion Problems in Nigeria. Journal of the Association of National Accountants of Nigeria; Lagos, Volume January - March, pp. 49 - 54.

Anyadiuba, J. O., Eragbhe, E. \& Kennedy, M. P., 2012. Deterrent Tax Measures and Tax Compliance in Nigeria. European Journal of Business and Management, 4(11), pp. 37 - 44.

Braithwaite, V. \& Braithwaite, J., 2000. An evolving compliance model for tax enforcement. In: Crimes of privilege. New York: Oxford University Press.

Chau, G. \& Leung, P., 2009. A critical review of Fischer's tax compliance model: A research synthesis. Journal of Accounting and Taxation, 1(2), pp. 34 - 40.

Kirchler, E., 2007. The economic psychology of tax behaviour. Cambridge: Cambridge University Press.

Nzotta, S. M., 2007. Tax Evasion Problems in Nigeria. Journal of the Institute of Chartered Accountants of Nigeria, Lagos, Volume April/June.

Ocheni, S., 2015. A Causality Analysis between Tax Compliance Behaviour and Nigerian Economic Growth. Mediterranean Journal of Social Sciences, 6(1), pp. 577 - 582.

Ojo, A. E. \& Oladipo, F. O., 2017. Tax and Taxation in Nigeria: Implications on the Construction Industry Sector. International Journal of Civil Engineering, Construction and Estate Management, 5(4), pp. 44 - 57.

Okoye, p. V. C., Akenbor, C. O. \& Obara, L. C., 2012. Promoting Sustainable Tax Compliance in the Informal Sectorin Nigeria. International Journal of Arts and Humanities, 1(1), pp. 40 - 54.

Roth, J. A., Scholz, J. T. \& Dry-Witte, J. T., 1996. Taxpayer compliance: An agenda for research, vol.1. Philadelphia: University of Pennsylvania Press. 